\title{
Naturalistic gardens as a recommended solution for the conservation of local biodiversity in degraded areas
}

\author{
Ewa Hanus-Fajerska ${ }^{1}$, Iga Karczewska ${ }^{1}$, Krystyna Ciarkowska ${ }^{2}$ \\ ${ }^{1}$ Department of Botany and Plant Physiology \\ Faculty of Horticulture, University of Agriculture in Krakow \\ 29 Listopada 54, 31-425 Kraków, Poland \\ ${ }^{2}$ Department of Soil Science and Soil Protection \\ Faculty of Agriculture and Economics, University of Agriculture in Krakow \\ Al. Mickiewicza 21, 31-120 Kraków, Poland \\ e-mail: ehanus@ogr.ar.krakow.pl
}

\begin{abstract}
The development of the art of garden design has brought about the emergence of naturalistic or ecological gardens. This paper presents a brief historical overview of this period in gardening, and provides examples of contemporary applications. Plants can function as absorbents of metals and therefore there is also the possibility of their practical application in techniques for purifying the environment from metallic contamination. An urgent need to create collections of this unique wild plant material has been stressed. Naturalistic gardens designed in appropriate areas have been proposed as an adequate form of setting up in vivo collections composed of numerous native taxa.
\end{abstract}

Key words: naturalistic planting design, preserving native vegetation, wasteland

\section{THE HISTORICAL OVERVIEW}

The initial period of creating landscape gardens, usually referred to as sentimental style parks, dates back to the 18th century. The eighteenth-century landscape park was mainly distinguished by its serenity, and its numerous features - that is, grass, trees, water, sky and pavilions - generated a series of natural, interesting views imitating paintings. According to the project, the garden was irregular in shape, unrestrained and asymmetrical. Trees were allowed to spread without restraint across the spacious lawns. An important feature was the depths of the lakes in which the surrounding landscape was reflected. Meandering paths, streams and brooks were constructed. It was William Kent who mostly contributed to bringing classical landscape parks and gardens into existence. According to Kent, this kind of arranged space should connect naturally with the background. Therefore, the features of the surrounding scenery influenced the formation of the garden space, which freely blended into the environment. Kent utilised different artefacts like statues, temples, pavilions, and other components such as plant arrangements, like solitary growing trees or groups of plants, which diversified the lawns. The most famous amongst his compositions is Rousham, situated alongside the Cherwell River in Oxfordshire, whose design has remained up till now almost unchanged. The continuator of Kent's ideas was Lancelot Brown, nicknamed "Capability Brown", as he used to investigate properties with reference to their capabilities. His creative activity was defined as "the quintessence of English landscape style", because he truly possessed the ability to copy nature in an extremely realistic manner. The essential features in Brown's gardens were grassland, trees, and in particular, stagnant 
water, reflecting the light and surroundings. The garden terrain was shaped in such a way that it appeared to be natural, with valleys, numerous lakes, small rivers or streams. A special quality of his projects was the maintenance of a garden fence, notably covered with trees (Hobhouse 2007, Brooks 2009, Majdecki 2009).

In Poland, three distinct types of naturalistic planting designs were created. They were sentimental, romantic and landscape gardens. The undertaking of the sentimental garden was formed under the influence of ideas glorifying a return to nature and adoration of the idyllic lifestyle, so attention was concentrated on the emotionality and perception of feelings. In the arrangement of gardens, there was a certain link between the geometric and landscape features, and it was vital for symbolic representations of philosophy and poetics to prevail. The most notable sentimental garden is Eden (Arkadia) near Łowicz, founded by Helena Radziwiłł in 1778. This garden has really stood the test of time, and as one among numerous masterpieces has existed with few changes till now. On the other hand, classical gardens were distinguished by a clear structure and rather limited number of tree and shrub species. They used an axial layout with an emphasis of the view from the front. For this period, manor-house gardens were typical, with rules according to which the forayhouse-main interior of the garden-remote view axis should be underlined. A good example is the Royal Baths Palace and Garden Complex founded by Stanisław August Poniatowski in Warsaw. As far as romantic gardens are concerned, they were created on the basis of both family and cultural traditions. The most eminent example is the Romantic Garden in Zofiówka near Humań, currently located in the Ukraine. Within the borders of Poland, the PalaceGarden Complex in Puławy has remained, with a garden resembling the typical English landscape style, founded by the Duchess Izabella Czartoryski (Bogdanowski 2000, Hobhouse 2007, Majdecki 1969, 2009).

During the 19th century, especially in the second half of the century, naturalistic gardens were created that aimed for a natural, unchanged form of landscape. It was quite a new tendency in garden creation to fully respect the natural layout. With this attitude in mind, the principles of composition were focused on integrating the natural and cultural, in an attempt to harmonise them. It was the indisputable beauty of pure nature that motivated the designers, and called to mind attempts to underline the qualities and value of an undisturbed local landscape. Noteworthy examples include Rogalin or Krzeszowice. However, naturalistic gardens frequently included created ample collections as well, rich in both local and exotic plant species, such as in Kórnik near Poznan. Throughout the history of the artistry of garden creation, naturalism has been connected with such characters as William Robinson, who wrote The Wild Garden and The English Flower Garden, Frank Waugh - the author of The Natural Style in Landscape Gardening, landscape architects Alvin Seifert and Jens Jensen, and Dutch biologist Jacobus Pieter Thijsse. Naturalism is also connected with the regular tendency of those times to initiate the preservation of the nature. Today, this indispensable attitude is still valid, and even more urgent to pursue. Among other forms of this activity, botanical gardens and arboreta are treated as places for biodiversity preservation, as scientific and didactic objects that should be specially emphasised, where special attention is given to the monitoring and preservation of endangered species, along with plant ecology and plant systematic studies. The oldest botanical garden in Poland is the Botanic Garden of the Jagiellonian University in Kraków, which was founded in 1783 following the reform of the University at the end of 18th century (Woudstra 1994, Bogdanowski 2000, Łukasiewicz and Puchalski 2002, Symonides 2008).

\section{CONTEMPORARY APPLICATIONS OF LANDSCAPE STYLE}

The cultural landscape has resulted in a large diversity of plant habitats. With the expansion of ecology movements, ever-increasing attention is being paid to the preservation of the natural environment in numerous countries of the world. The concept of natural garden design enjoys great popularity in view of the present progression of environmental contamination, involving fauna and flora exhaustion. Therefore, as far as contemporary applications of the naturalistic style are concerned, the tendency still exist towards perceiving gardens as spaces modelled after the natural beauty of the given region, where it is necessary to preserve native vegetation. This attitude is especially dominant in the United States of America, even though it has become a more and more popular approach in European countries as well, where ecological issues are a major concern of modern natural garden designs (Mc Nelly et al. 1995, Tokarska-Guzik 2000, Heatherington and Sargeant 2005). Thus, thanks to 
the previous creators of garden art, old ideas have evolved to incorporate modern attitudes. From such ideas, contemporary designers can create projects that are relevant in the present day. Apart from introducing naturalism into landscape architecture, the idea of public parks was simultaneously formed, in which inhabitants can experience a place where the spirit of nature comes to life. In public parks and gardens, flowerbeds are routinely used, and that is why they are usually localized in places that are most frequently visited and observed. When we undertake a project, it is significant to take into consideration the rate of growth of individual species and varieties and their mode of expanding in space. Essentially, in naturalistic gardens it is better to create sizeable plant groups in order to obtain brighter colourful effects. It is also advisable to use plant species flowering in spring together with those that bloom in the summer and in the autumn. Such species should be grown on the same place for a long time, and are expected to tolerate perennials characterized by vivid growth. Thus, currently naturalistic compositions can be defined as the art of creating a landscape we may assume to see in the wild, so the term 'naturalistic' can be easily replaced with 'ecological compositions' (Greiner and Weber 1997, Shukman 2004, Simon 2007, Zachariasz 2009).

The first municipal park with local vegetation in Europe was created by Jacobus Thijsse in south Amsterdam. Thijsse gathered plants that were characteristic for the terrain of whole country together. Today, naturalistic gardens are also extremely popular in Germany. In the Weihenstephan Institute Park located in Munich, rectangular flowerbeds are planted with different species of perennials, annual plants and shrubs representing individuals of the populations characteristic in that region. A good naturalistic garden should reflect nature and, as a result, should look like it has been created by nature. Garden designs from wild landscapes allow the emphasis of such qualities as light, colour changes through the seasons, plant architecture and diversity. The best possible approach is to only use specimens of locally existing flora. As a rule, introduced species are usually expansive, and can easily dominate those typical for the wildlife style garden. What is more, at the same time it is a unique possibility to preserve local biodiversity for both present and future generations (Woudstra 1994, Rostański et al. 2006, Zachariasz 2009). Meadows of flowers in the summer burst with life, with bees, butterflies and other insects buzzing around the flowers, and birds and smaller wild animals can easily find nourishment and hiding places among the nearby woody areas. Introducing the possibility to preserve local biodiversity in naturalistic gardens is truly a very important task because of its environmental, horticultural, medicinal, and even social value. Such fascinating places bursting with different life forms can be an ideal educational ground for pupils and students.

For all the above-mentioned reasons, the management of gardens that draw upon nature for specifically designed areas could be an especially valuable approach. It should be underlined that this form of creative activity would be especially valuable in industrially degraded areas, as such the kind of degradation of the environment that is visible not only as a physical distortion of the landscape, but also as a deformation of the soil, water and air chemistry. On the other hand, abandoned postindustrial lands left without any management could become sites where specific spontaneous vegetation develops to create ecological systems unique in the regional scale (Johnson and Bradshaw 1979, Cairns 2000, Rostański 2003, Porębska 2005). For instance, Books (1992) argues that many old mining sites in England have become of high value in regards to biodiversity and conservation because of both their native plant species or populations, and because they serve as refuge for plant and animal species whose natural habitats have been considerably reduced by a range of human activities. In Poland, old landfills can also be treated as valuable refuges for many protected or endangered and otherwise precious species (Grodzińska et al. 2000, Rostański 2000, Woźniak et al. 2003, Bzdęga et al. 2004). Trząski et al. (2006) proposed a standardised form for the visual assessment of the value of natural resources on post-industrial grounds. Both natural, seminatural and human-built naturalistic landscapes filled with colours and textures and with artfully created ponds and streams can bring about real contemplation. But the more natural the garden looks, the more artful the techniques employed by its designer must be. That is why both artistic skills and horticultural experience are essential in order to create a naturalistic garden that is properly adapted to all kinds of pre-existing site conditions.

\section{ECOLOGICAL SAFE DECONTAMINA- TION OF GROUND CONTAMINATED WITH HEAVY METALS}

Another crucial undertaking is the ecologically safe decontamination of soils and grounds polluted 
by heavy metals. It is a fact that ecosystems throughout the world have been contaminated, so in order to counteract environmental pollution, the beneficial impact of vegetation must be strictly taken into consideration, as plants are useful either in the monitoring or remediation of environmental states. It is almost needless to add, that due to their immutable nature, metals continue to constitute a group of pollutants of much concern. Nonessential heavy metals, such as arsenic, antimony, cadmium, chromium or lead, exemplify a particular problem. The remediation of sites, especially those contaminated with toxic levels of heavy metals, is particularly difficult, as, unlike organic compounds, metals cannot be degraded. For this reason, the only possible approach is to remove them from the environment (Lasat 2002, Alkorta et al. 2004, Ghosh and Singh 2005). Elevated levels of heavy metals, which are present in soil and wastewater used for agricultural irrigation, lead to their bioaccumulation in crops, and as a result, endanger public health (Sady and Smoleń 2004, Sękara et al. 2005, Figura and Pluta 2006, Pavliková et al. 2007). During the last decade, significant progress has been made in phytoremediation, the green and inexpensive method to safely remove numerous contaminants from soil and water. Currently, in situ techniques are favoured over those ex situ, mainly due to their reduced impact on the ecosystem. Vascular plants are one of the most important groups of organisms, significant for the efficiency of their phytoremediation abilities (Barley et al. 2005, Padmavathiamma and Li 2007, Vamerali et al. 2009). Provided that the metal is mobilised into the soil solution, phytoextraction is the best suited to resolve heavy metal contamination of soil without destroying its structure and fertility from the available phytoremediation techniques (Ghosh and Singh 2005, Usman and Mohamed 2009). The effectiveness of all known phytoremediation techniques is equally dependent on plant and site characteristics. Phytoextraction makes use of socalled "hyperaccumulators" - metal accumulating plant species that can concentrate metals in their aboveground parts to levels far exceeding the concentration of the respective element in the soil; the term was introduced in 1977 by Brooks and fellow researchers (Brooks et al. 1977). Hyperaccumulators accumulate considerable quantities of metal in their biomass regardless of the concentration of such metallic elements in the substrate (Baker 1981). Plant species capable of hyperaccumulating heavy metals are also of considerable interest because of their potential use in phytomining (Robinson et al. 1997, Gałuszka 2005, Padmavathiamma and Li 2007). Hyperaccumulators are rather rare in comparison to the occurrence of many other plant species, even if more than four hundred species have been described to date. They possess suitable physiological and anatomical characteristics, enabling them to occupy unique ecological niches in the natural environment, and are localised in geographically distant areas of the world (Baker and Brooks 1989, Reeves 2006). At present, some of these plants species have become quite rare as a consequence of devastation from mining and metallurgic activities. Metal hyperaccumulating plants with the ability to tolerate, accumulate and detoxify metals and metalloids represent an important reservoir of unique genes, vital to both the basic and applied research community in order to make progress in technologies in which plants are used either to remove pollutants from the environment or render them harmless. Thus, with the aim to restore environmental balance, there is an underlined urgent need to collect these materials and bring them into cultivation for future research and trial work (Pollard 2000, Bech et al. 2002, Prasad and Freitas 2003, Shah and Nongkynrih 2007). Naturalistic gardens designed in appropriate territories are proposed as the most adequate form of setting up such collections in vivo.

\section{CONCLUSIONS}

1. Nineteenth-century naturalism in the art of garden creation has become inseparably connected with the concept of natural preservation.

2. Owing to the previous creators of garden art, modern designers have benefited from original ideas in contemporary applications of landscape style.

3. It is possible to purify the ground with the use of appropriate native plant species.

4. Naturalistic garden creation is a favourable form of preserving local flora and fauna.

\section{REFERENCES}

Alkorta I., Hernnandez-Allica J., Becceril J.M., Amezaga I., Onaindia M., Garbitsu C., 2004. Chelate-enhanced phytoremediation of soils polluted with heavy metals. Rev. Environ. Sci. Biotechnol. 1-4: 55-70.

BAKER A.J.M., 1981. Accumulators and excluders strategies in the response of plants to heavy metals. J. Plant Nutr. 3: 643-654. 
BAKer A.J.M., Brooks R.R., 1989. Terrestrial higher plants which hyperaccumulate metallic elements a review of distribution, ecology and biochemistry. Biorecovery 1: 81-126.

Barley R.W., Hutton C., Brown M.E., Cusworth J.E., Hamilton T.J., 2005. Trends in biomass and metal sequestration associated with reeds and algae at Wheal Jane Biorem pilot passive treatment plant. Sci. Total Environ. 338(1-2): 107-114.

Bech J.C., Poschenrieder B.J., Barceló A., Lansac A., 2002. Plants from mine spoils in the South American area as potential source of germplasm for phytoremediation technologies. Acta Biotechnol. 22(1-2): 5-11.

Bogdanowski J., 2000. Polskie ogrody ozdobne. Historia i problemy rewaloryzacji. Arkady, Warszawa.

Books J., 1992. Conservation or greening? The challenge of post-industrial landscapes. Brit. Wildlife 4: 273-279.

Brooks R.R, Lee J., Reeves R.D., Jaffre T., 1977. Detection of nickeliferous rocks by analysis of herbarium specimens of indicator plants. J. Geochem. Expl. 7: 49-57.

Brooks J., 2009. Projektowanie ogrodów. Hachette Polska, Warszawa.

Bzdęga K., Pasierbiński A., Chmura D., 2004. The role of post-coal mine heaps in the maintenance of regional floristic diversity in the Upper Silesia region. Chrońmy Przyrodę Ojczystą 60(2): 17-32.

CAIRns JR. J., 2000. Setting ecological goals for technical feasibility and scientific validity. Ecol. Eng. 15: 171-180.

Figura B., Pluta J., 2006. Evaluation of purity of certain paediatric preparations of plant origin and its significance for the safety of pharmacotherapy. Part 1. Heavy metals contamination of certain paediatric preparations of plant origin. J. Elementol. 11(3): 283-294.

GAŁuszKa A., 2005. Wykorzystanie mikroorganizmów i roślin do pozyskiwania metali. Przegląd Geolog. 53: 858-862.

Ghosh M., Singh S.P., 2005. A review on phytoremediation of heavy metals and utilization of its byproducts. Appl. Ecol. Environ. Res. 3(1): 1-18.

Greiner K., Weber A., 1997. Nowoczesny ogród. Wyd. Kaliope, Warszawa.

Grodzińska K., Korzeniak U., Szarek-Łukaszewska G., GoDziK B., 2000. Colonization of zinc mine spoils in southern Poland - preliminary studies on vegetation, seed rain and seed bank. Fragm. Flor. Geobot. 45(12): 123-145.

Heatherington C., Sargeant J., 2005. A new naturalism. Packard Publ. Ltd. Chicchester, West Sussex.

Hobhouse P., 2007. Historia ogrodów. Arkady, Warszawa.

Johnson M.S., Bradshaw A.D., 1979. Ecological principles for the restoration of disturbed and degraded land. Adv. Appl. Biol. 4: 141-200.
LASAT M.M., 2002. Phytoextraction of toxic metals: a review of biological mechanisms. J. Environ. Qual. 31(1): 109-120.

Łukasiewicz A., Puchalski J. (eds), 2002. Ogrody botaniczne w Polsce. ARW i Fund. Homo et Planta, Warszawa.

Mc Nelly J.A., Gadgil M., Leveque C., Padoch C., REDFORD K., 1995. Human influence on biodiversity. In: Global biodiversity. Cambridge University Press: 711-822.

Majdecki L., 1969. Przemiany formy i konserwacja. Łazienki. Przemiany układu przestrzennego założenia ogrodowego. PWN, Warszawa.

MAJdecki L., 2009. Historia ogrodów. Tom 2: Od XIII wieku do współczesności. PWN, Warszawa.

Padmavathiamma P.K., Li L.Y., 2007. Phytoremediation technology: hyper-accumulation metals in plants. Water Air Soil Poll. 184: 105-126.

Pavlikova D., Balik J., Tlustos P., 2007. Effect of cadmium content in soil and crop rotation on cadmium accumulation in plant biomass. Ecol. Chem. Engin. 14(3-4): 363-369.

Pollard A.J., 2000. Metal hyperaccumulation a model system for coevolutionary studies. New Phytol. 146: 179-181.

PoręBSKA G., 2005. The new quality of environment and landscape in post-industrial areas. Ochr. Środ. i Zasobów Natur. 28: 15-23.

Prasad M.N.V., Freitas H.M., 2003. Metal hyperaccumulation in plants - biodiversity prospecting for phytoremediation technology. El. J. Biotechnol. 6(3): 285-320.

REEVES R.D., 2006. Hyperaccumulation of trace elements by plants. In: Phytoremediation of metalcontaminated soils. J.L. Morel, G. Echevarria, N. Goncharova (eds), Springer: 25-52.

Robinson B.H., Chiarucci A., Brooks R.E., Petit D., Kirkman J.H., Gregg P.E.H., De Dominics V., 1997. The nickel hyperaccumulator plant Alyssum bertolonii as a potential agent for phytoremediation and phytomining of nickel. J. Geochem. Explor. 59: 75-86.

RostaŃSki A., 2000. Spontaneous flora of post-industrial sites of the Upper Silesia region. Acta Biol. Siles. 35: 131-154.

Rostański A. Woźniak G., Tokarska-Guzik B., 2006. Spontaneous processes in revitalization of postindustrial areas - controversies and solutions. Czasop. Techn. Z8-A: 75-86.

RostAŃSKI K.M., 2003. Natural succession as a method of bringing into cultivation a post industrial areas. Mat. Konf. Nauk. „Kształtowanie krajobrazu terenów poeksploatacyjnych w górnictwie”, 10-12 grudnia, Kraków: 145-154.

SAdy W., Smoleń S., 2004. Wpływ czynników glebowonawozowych na akumulację metali ciężkich w roślinach. Rocz. AR w Poznaniu, ser. Ogr. 37: 296-277. 
Sęrara A., Poniedzialek M., Ciura J., Jęddraszczyk E., 2005. Cadmium and lead accumulation and distribution in organs of nine crops: implications for phytoremediation. Pol. J. Environ. Stud. 14(4): 509-516.

Shah K., Nongkynrih J.M., 2007. Metal hyperaccumulation and bioremediation. Biol. Plant. 51(4): 618-634.

ShuKman J., 2004. Rabaty ogrodowe. Efektowne zestawienia roślin w każdych warunkach. Świat Książki, Warszawa.

Simon H., 2007. Kwiaty lata. Muza S.A., Warszawa.

Symonides E., 2008. Ochrona przyrody. Wyd. Uniwersytetu Warszawskiego, Warszawa.

Tokarska-GuziK B., 2000. Przyrodnicze zagospodarowanie nieużytków miejsko-przemysłowych na przykładzie centrów górniczych Europy. Inż. Ekol. 1: 72-80.

Trząski L., Caruk M., Olszewski P., Zdebik D., 2006. Proposition of the form for visual assessment of natural-cultural resources on the post-mining and post-industrial grounds. Prace Naukowe GIG, Górnictwo i Środowisko 1: 47-61.

Usman A.R.A., Mohamed H.M., 2009. Effect of microbial inoculation and EDTA on the uptake and translocation of heavy metal by corn and sunflower. Chemosphere 76: 893-899.

Vamerali T., Bandiera M., Coletto L., Zanetti F., Dickinson N., Mosca G., 2009. Phytoremediation trials on metal- and arsenic-contaminated pyrite wastes (Torviscosa, Italy). Environ. Poll. 157: 887-894.

Woudstra J., 1994. Jacobus P. Thijsse's influence on Dutch landscape architecture. In: Nature and Ideology. Natural garden design in the twentieth century. J. Wolschke-Bulmahn (ed.), Dumbarton
Oaks Trustees for Harvard University, Washington D.C.: $155-186$.

WoźNiak G., Pasierbiński A., Rostański A., 2003. The diversity of spontaneous woodland vegetation on coals mine heaps of Upper-Silesian region. Archives Environ. Prot. 29(2): 93-105.

ZaChARIAsz A., 2009. Współczesne kierunki i tendencje w projektowaniu parków publicznych. Nauka Przyr. Technol. 3(1): 1-10.

\section{OGRODY NATURALISTYCZNE JAKO ROZWIAZZANIE ZALECANE W CELU ZACHOWANIA BIORÓŻNORODNOŚCI NA TERENACH ZDEGRADOWANYCH}

Streszczenie: Wraz z rozwojem sztuki ogrodowej powstawały kompozycje określane jako ogrody naturalistyczne, które pomimo iż były tworzone przez projektantów stwarzały wrażenie powołanych do życia przez samą naturę. Dokonano krótkiego przeglądu historycznego tego okresu w historii ogrodów oraz wskazano kilka współczesnych przykładów zastosowania tego typu kompozycji. Wspomniano również o możliwości zastosowania roślin $\mathrm{w}$ technikach oczyszczania środowiska $\mathrm{z}$ zanieczyszczeń metalicznych dzięki wykorzystaniu ich funkcji fizjologicznych. Podkreślono pilną potrzebę tworzenia kolekcji tych unikalnych roślin dziko rosnących. Ogrody naturalistyczne zaprojektowane na odpowiednim obszarze proponowane są jako odpowiednia forma tworzenia takich kolekcji w warunkach in vivo.

Received September 17, 2009; accepted December 17, 2010 